\title{
Sistem Informasi Ketersediaan Ruangan Rumah Sakit Terintegrasi Aplicare BPJS Kesehatan
}

\author{
Albert Riyandi \\ STMIK NUSA MANDIRI JAKARTA \\ e-mail: mausharing@gmail.com
}

Cara Sitasi: Riyandi, A. (2019, Maret). Sistem Informasi Ketersediaan Ruangan Rumah Sakit Terintegrasi Aplicare BPJS Kesehatan. (S. Dalis, Ed.) Paradigma - Jurnal Komputer dan Informatika, 21(1), 85-90. doi:10.31294/p.v21i1.5072

\begin{abstract}
- health is a very basic thing in the needs of every human being this is also regulated in the 1945 Constitution. The government in realizing health services mandated by the law has a national health insurance program (JKN) organized by the Health Social Security Organizing Agency (BPJS Health). This JKN program until December 31, 2017 the number of participants who participated had reached 187,982,949 which means 72.9\% of the Indonesian population. Aplicares is an application of a health BPJS that functions to find locations and information about the desired health facilities that can be seen on the web of health facilities.bpjskesehatan.go.id/aplicares. Hospitals that have collaborated with health BPJS are required to be able to enter the room data they have into the aplicares and be updated continuously even in real time. Poor hospitals IT experts who understand programming languages have difficulty entering data because BPJS Health only provides scripting and examples of programming languages. Existing Hospital Information Systems (SIM-RS) are usually made by Developer Systems outside of Hospital staff, so to add new modules must add additional costs. With the Information System Availability of Integrated Hospital Rooms with BPJS Health Aplicares that are built with Motede Waterfall, it becomes the solution to these problems.
\end{abstract}

Keywords: JKN, BPJS Kesehatan,SIM-RS, Waterfall, Room Information System

\section{PENDAHULUAN}

\subsection{Latar Belakang Masalah}

Kesehatan merupakan hal yang sangat mendasar dalam kebutuhan setiap manusia sebagaimana Undang-undang Dasar 1945 pasal 28 H ayat 1 (satu) dan pasal 34 ayat 3 (tiga) mengamanatkan bahwa negara menjamin hak setiap warga negara untuk memperoleh pelayanan kesehatan dan fasilitas pelayanan kesehatan. Dalam menjamin pelayanan kesehatan pemerintah menyelenggarakan Program Kesehatan Nasional (JKN) yang diselenggarakan oleh Badan Penyelenggara Jaminan Sosial kesehatan atau yang lebih dikenal BPJS Kesehatan. Program Jaminan Kesehatan ini dijalankan sesuai dengan Undang-Undang Nomor 40 tahun 2004 tentang Sistem Jaminan Sosial Nasional (SJSN).

Menurut data BPJS Kesehatan Program Jaminan Kesehatan Nasional - Kartu Indonesia Sehat (JKNKIS) pada 31 Desember 2017 jumlah peserta sudah mencapai 187.982.949 yang berarti $72,9 \%$ dari penduduk indonesia sudah mengikuti program JKN tersebut (BPJS, 2018).
BPJS Kesehatan wajib melaporkan kepada pemerintah tentang fasilitas yang bekerjasama dengan BPJS Kesehatan sesuai dengan Peraturan Menteri Kesehatan nomor 99 tahun 2015. Untuk mempermudah pendataan, pencarian dan dapat di akses secara publik terutama tentang data ketersediaan fasilitas ruangan Rumah Sakit, maka BPJS mewajibkan seluruh Rumah Sakit yang sudah bekerja sama untuk dapat melaporkan kondisi Bad Room secara real time atau berkala ke dalam website faskes.bpjs-kesehatan.go.id/aplicares. Aplicares ini berfungsi mencari lokasi dan informasi tentang faskes yang diinginkan serta memandu menuju lokasi yang dipilih (BPJS, 2018).

Dalam pengisian data ke portal tersebut, BPJS Kesehatan tidak menyediakan aplikasi khusus untuk dapat menghubungkan antara Sistem Informasi Rumah Sakit (SIM-RS) yang dimiliki Rumah Sakit ke sistem Aplicares. Untuk menghubungkan ke portal tersebut, BPJS Kesehatan hanya memberikan scripting dan contoh bahasa pemrograman.

Rumah Sakit yang tidak mempunyai tenaga ahli IT yang mengerti bahasa pemrograman, tentunya sangat kesulitan dengan hal ini. Ditambah lagi 
Sistem Informasi Rumah Sakit (SIM-RS) yang ada saat ini kebanyakan Outsource dari penyedia Development System diluar dari karyawan Rumah Sakit yang tentunya akan menambah beban biaya untuk dapat terintegrasi.

Perancangan aplikasi dengan model waterfall sangat efektif dilakukan untuk merancang sebuah sistem, baik dari awal maupun untuk rencana kedepan dari sebuah sistem informasi dengan tepat dan cepat (Riyandi, 2018). Model waterfall dirasa efektif untuk menyelesaikan Aplikasi Sistem Informasi Ketersedian Ruangan Rumah Sakit Terintegrasi Aplicares BPJS Kesehatan. Dengan bahasa pemrograman PHP dan MySql Sebagai database mejadikan solusi terbaik untuk permasalahan diatas.

\subsection{Rumusan Masalah}

Dari uraian diatas dapat dirumuskan sejauh mana tingkat efektifitas perancangan aplikasi sistem informasi ketersediaan ruangan rumah sakit terintegrasi aplicares BPJS Kesehatan dengan menggunakan metode waterfall?

\subsection{Ruang Lingkup Peneliian}

Penelitian ini berfocus pada perancangan aplikasi sistem informasi ketersediaan ruangan rumah sakit terintegrasi aplicares BPJS Kesehatan dengan menggunakan metode waterfall terdiri dari 5 tahapan yaitu:

a. Analisis Kebutuhan Perangkat Lunak

b. Design Sistem

c. Pembuatan Kode Program

d. Pengujian

e. Pendukung dan pemeliharaan

\subsection{Tujuan dan Manfaat Penelitian}

Penelitian ini bertujuan untuk merancang sebuah sistem informasi ketersediaan ruangan rumah sakit terintegrasi aplicares BPJS Kesehatan yang memberikan kemudahan kepada Rumah Sakit yang tidak mempunyai tenaga ahli IT.

Manfaat dari peelitian ini adalah :

a. Dapat digunakan sebagai acuan dalam membangun sistem informasi ketersediaan Rumah Sakit dalam skala lengkap (SIM-RS) yang terintegrasi dengan Aplicares BPJS Kesehatan

b. Memberikan sumbangsih pemikiran dalam pemahaman akan penerapan model waterfall dalam perancangan sebuah sistem

\section{METODOLOGI PENELITIAN 2.1 Teknik Pengumpulan Data}

Metode penelitian adalah cara yang digunakan oleh peneliti dalam pengumpulan data penelitiannya (Arikunto, 2006). Metode Penelitian pada dasarnya merupakan cara ilmiah untuk mendapatkan data dengan tujuan dan kegunaan tertentu (Sugiono, 2010). Dari pengertian tersebut diatas maka dapat diartikan bahwa metode penetian adalah sebuah cara ilmiah yang digunakan oleh peneliti dalam mengumpulkan fakta dan data dengan tujuan tertentu untuk digunakan dalam penelitiannya.

Dalam melakukan penelitian ini dilakukan teknik pengumpulan data yang dilakukan untuk memahami permasalahan yang terjadi, yaitu :

a. Observasi, proses pengamatan yang dilakukan secara langsung. Dalam penelitian ini Ciputra Hospital sebagai tempat melakukan penelitian

b. Wawancara, proses tanya jawab seputar penelitian yang dilakukan untuk memperoleh informasi lebih dalam, baik terhadap IT Rumah Sakit maupun IT BPJS Kesehatan

c. Studi pustaka, proses pemahaman materi seputar penelitian yang dilakukan dengan memperoleh informasi dari artikel-artikel jurnal ilmiah, website, serta buku

\subsection{Metode Pengembangan Sistem}

Suatu sistem dapat diartikan sebagai suatu kumpulan atau himpunan dari unsur, komponen, atau variabel yang terorganisir, saling berinteraksi, saling tergantung satu sama lain, dan terpadu (Sutabri, 2012:10).

Adapun metode pengembangan sistem yang digunakan adalah metode waterfall yang terdiri dari 5 tahapan (S \& Shalahuddin, 2014), yaitu :

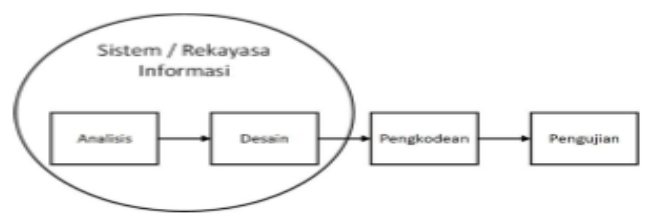

Sumber: (S \& Shalahuddin, 2014).

Gambar 1. Model Waterfall.

a. Analisis Kebutuhan perangkat lunak, proses pengumpulan kebutuhan yang dilakukan secara intensif untuk menspesifikasikan kebutuhan sistem agar dapat mudah dipahami. Pada tahap ini dilakukan dokumentasi kebutuhan sistem 
untuk membangun aplikasi yang dibutuhkan serta dapat terintegrasi.

b. Desain sistem, pada tahapan ini focus pada perancangan struktur basis data, arsitektur sistem serta rancangan antar muka. Tahap ini mentranslasi kebutuhan sistem dari tahap analisis kebutuhan sistem ke representasi desain agar dapat dilanjutkan pada tahap pembuatan program / pengkodingan

c. Pembuatan kode program, mentranslasikan apa yang sudah dibuat dalam desain sistem kedalam sebuah program menggunakan bahasa pemrograman tertentu. Hasil dari tahapan ini adalah program komputer sesuai dengan desain yang sudah dibuat.

d. Pengujian, pada proses ini dilakukan pengujian dari program yang sudah dibuat yang berfokus pada fungsional untuk memastikan masukan atau keluaran sistem telah sesuai dengan kebutuhan pengguna

e. Pendukung dan pemeliharaan, dalam sebuah sistem tidak menutup kemungkinan terjadi perubahan-perubahan aturan bisnis yang ada dan harus beradaptasi dengan lingkungan yang baru. Pada tahapan ini dapat dilakukan pengunalangan proses pengembangan sistem mulai dari menganalisis kebutuhan sistem yang ada dengan memaksimalkan aplikasi yang sudah ada (tidak membuat baru)

\section{HASIL DAN PEMBAHASAN}

Dari hasil teknik pengumpulan data dilakukan analisa terhadap aturan sistem yang ditetapkan. Dapat diambil beberpa proses yang dapat dilihat pada gambar berikut:

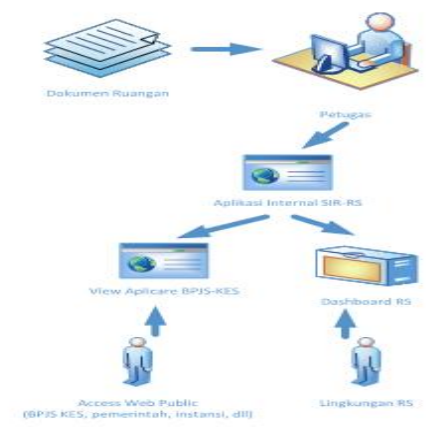

Sumber (Riyandi, 2018)

Gambar 2. Proses Sistem

a. Proses memasukkan data, pada proses ini memasukan data ruangan yang dilakukan oleh petugas dari Rumah Sakit ke dalam sebuah sistem

b. Proses integrasi, pada proses ini dilakukan oleh sistem dalam mensingkronkan data yang dimasukkan oleh petugas ke dalam sistem dengan data sistem Aplicares BPJS Kesehatan

c. Proses Monitoring \& Laporan, setelah dilakukan proses memasukkan data dan integrasi, maka dilakukan proses monitoring untuk melihat hasil yang sudah ada apakah sudah sesuai dan dapat dilihat oleh publik melalui website Aplicares BPJS Kesehatan maupun dashboard internal Rumah Sakit serta lapporan terhadap management.

\subsection{Diagram Alir Data}

Diagram alir data menggambarkan pandangan sejauh mungkin mengenai masukan, proses, dan keluaran sistem yang berhubungan dengan masukan, proses dan keluaran dari model sistem (Kendall \& Kendall, 2010:263). Dari hasil analisa yang dilakukan diatas, untuk perancangan pembuatan aplikasi sistem informasi ketersediaan ruangan Rumah Sakit terintegrasi dengan Aplicares BPJS Kesehatan dapat diketahui bentuk sistem garis besar diagram konteks, diagram nol, dan diagram detail yang menggambarkan diagram alir data dapat dilihat pada gambar dibawah ini

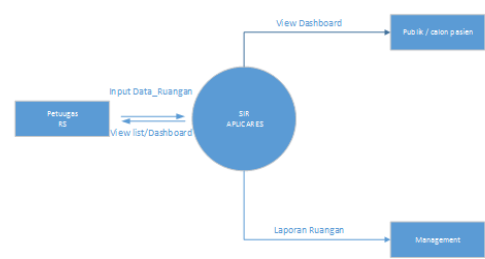

Sumber (Riyandi, 2018)

Gambar 3. Diagram Konteks

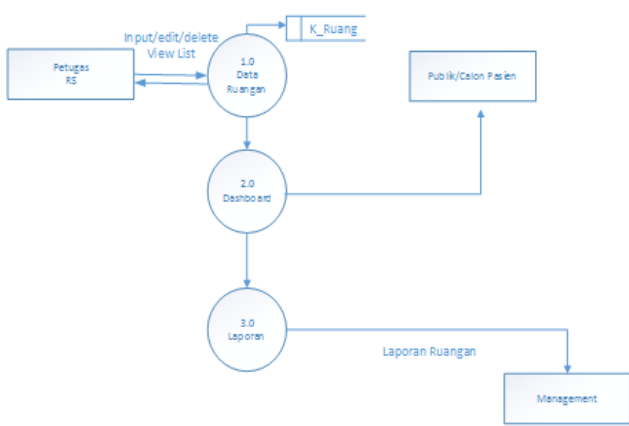

Sumber (Riyandi, 2018)

Gambar 4. Diagram Nol 


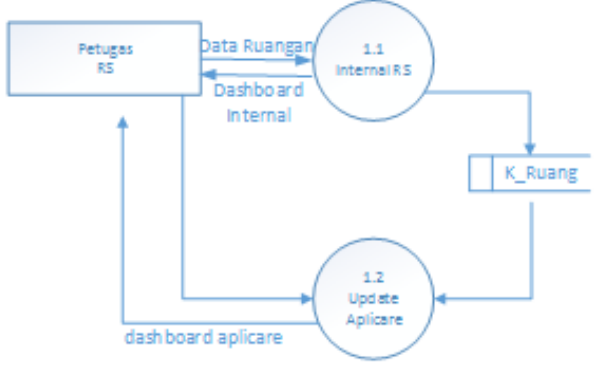

Sumber (Riyandi, 2018)

\subsection{ERD dan LRS}

Entity Relationship Diagram (ERD) adalah suatu model data yang dikembangkan berisi himpunan entitas dan relasi yang dilengkapi dengan atribut yang mempresentasikan secara sistematis dari tabel data yang ditinjau (Riyandi, 2018). Entity Relationship Diagram (ERD) merupakan suatu model data yang dikembangkan berdasarkan objek (Sutanta, 2011:91).

Dari diagram alir data yang ada maka dibuat ERD (Entity Relationship Diagram) dan LRS (Logical Relational Structur). Hal ini bertujuan untuk menjelaskan hubungan antar data dalam basis data sehingga dapat diketahui dengan jelas model data yang digunakan untuk membuat aplikasi sistem informasi ketersediaan ruangan Rumash Sakit terintegrasi dengan Aplicares BPJS Kesehatan. ERD dan LRS Sistem Informasi ketersedian ruangan Rumah sakit terintegrasi Aplicares BPJS Kesehatan dapat dilihat pada gambar dibawah ini.

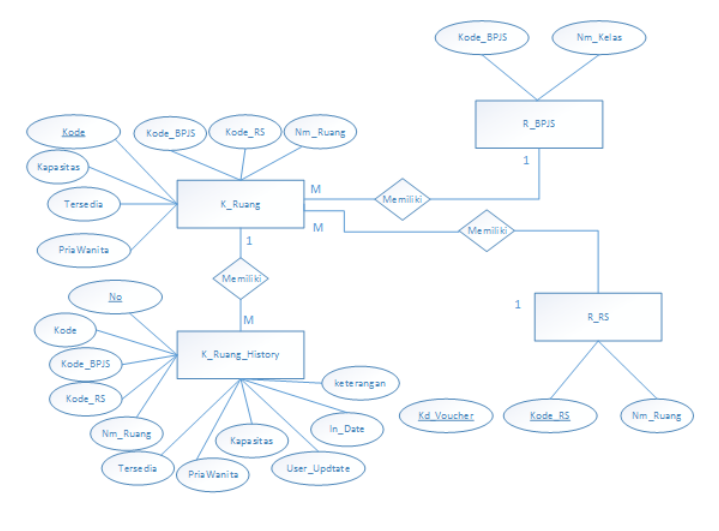

Sumber (Riyandi, 2018)

Gambar 6. ERD

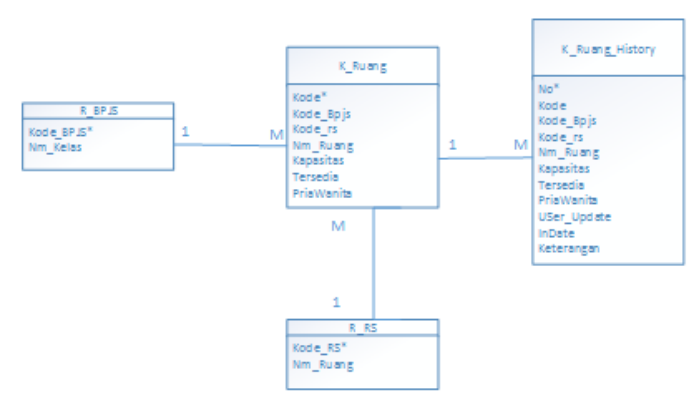

Sumber (Riyandi, 2018)

Gambar 7. LRS

\subsection{HIPO (Hierarcy Input Proses Output)}

HIPO (Hierarcy Input Proses Output) adalah alat desain dan teknik dokumentasi dalam siklus pengembangan sistem (Jogiyanto, 2005 : 787). Dari pengertian tersebut dan hasil diagram yang sudah dibuat maka dikembangkan HIPO untuk Sistem Informasi ketersediaan ruangan Rumah Sakit terintegrasi dengan Aplicares BPJS Kesehatan sebagai berikut :

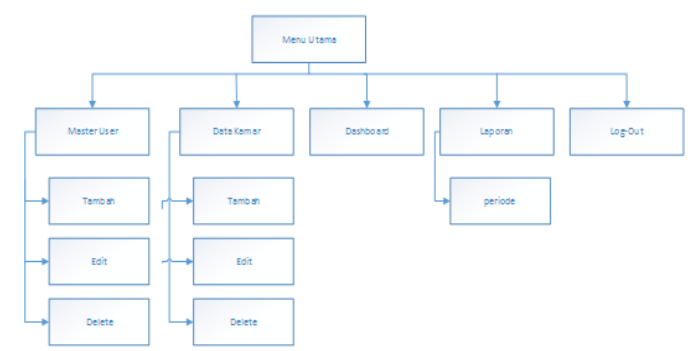

Sumber (Riyandi, 2018)

Gambar 8. HIPO

\subsection{Implementasi}

Dari penjabaran diatas maka dihasilkan sebuah aplikasi sistem informasi ketersediaan ruangan Rumah Sakit terintegrasi Aplicares BPJS Kesehatan. Berikut adalah implementasi desain dengan menggabungkannya ke dalam bahasa pemrograman.

\section{HOSPITAL APLICARES}

DASHBOARD ROOM

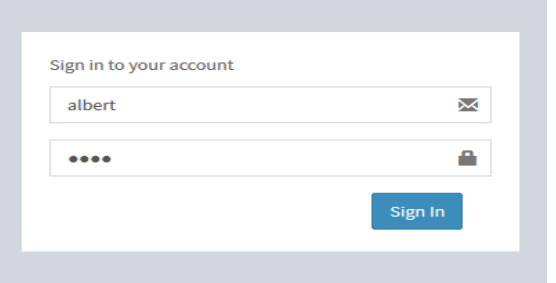

Sumber (Riyandi, 2018)

Gambar 9. Login 


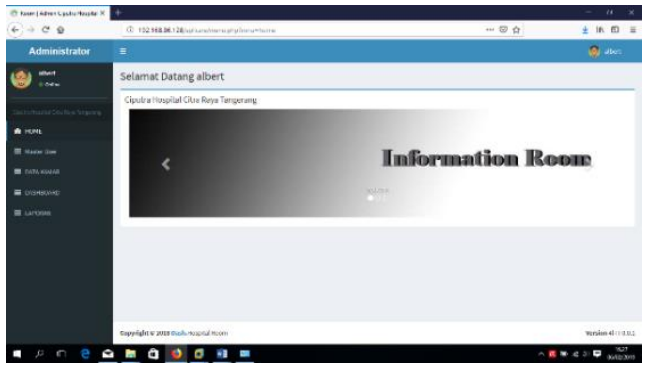

Sumber (Riyandi, 2018)

Gambar 10. Menu Utama

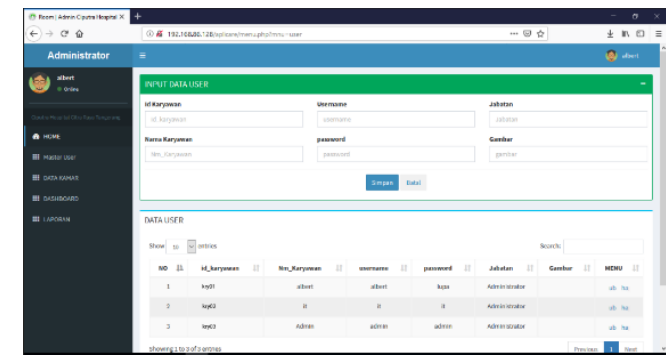

Sumber (Riyandi, 2018)

Gambar 11. Master User

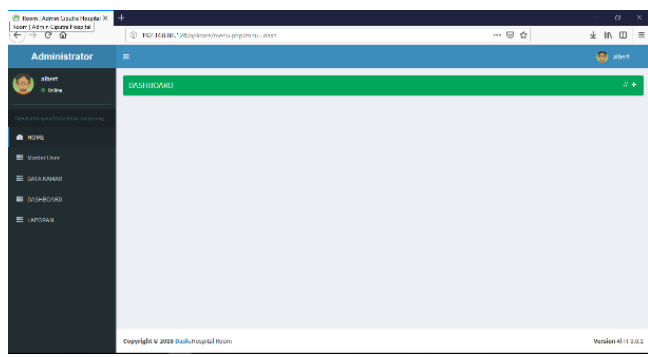

Sumber (Riyandi, 2018)

Gambar 12. Data Ruangan

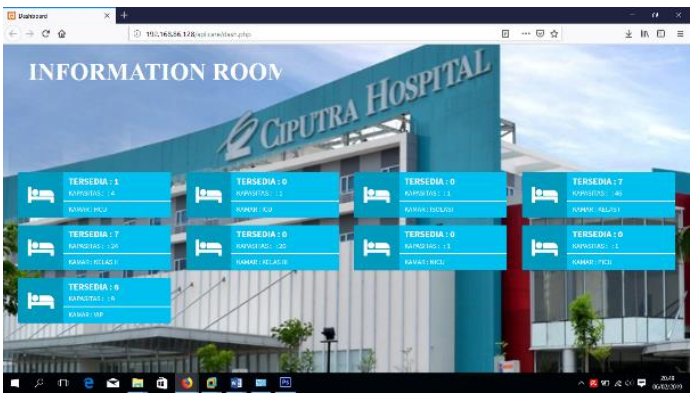

Sumber (Riyandi, 2018)

Gambar 13. Dashboard RS

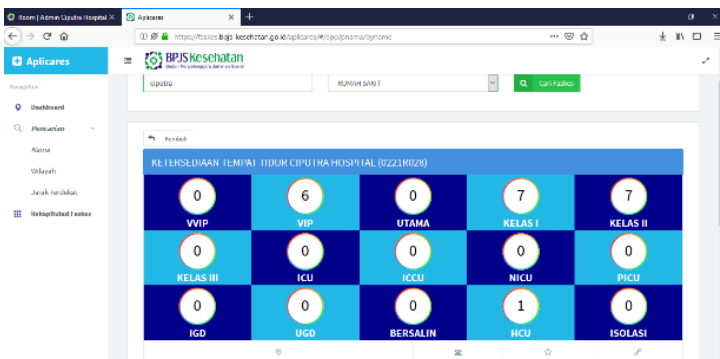

Sumber (Riyandi, 2018)

Gambar 14. Dashboard Aplicare BPJS Kesehatan

\subsection{Pengujian}

Setelah dilakukan pembuatan aplikasi langkah yang paling penting adalah melakukan pengujian terhadap aplikasi yang sudah dibuat. Dengan metode pengujian blackbox menguji aplikasi sistem informasi ketersediaan ruangan Rumah Sakit terintegrasi Aplicares BPJS Kesehatan secara fungsional sesuai dengan kebutuhan sistem pengguna.

Tabel dibawah inimenyajikan pengujian baik login, input data ruangan, maupun monitoring view yang dapat dilihat secara real baik dilingkungan dashboard Rumah Sakit maupun melalui web Aplicares BPJS Kesehatan

Tabel 1. Pengujian Blackbox

\begin{tabular}{|c|c|c|c|c|}
\hline No & Pengujian & $\begin{array}{l}\text { Hasil yang } \\
\text { diharapkan }\end{array}$ & Keterangan & Hasil \\
\hline 1 & $\begin{array}{l}\text { Mengisi Form } \\
\text { Login dan klik } \\
\text { tombol login }\end{array}$ & $\begin{array}{l}\text { masuk ke } \\
\text { main menu }\end{array}$ & $\begin{array}{l}\text { Jika diinput } \\
\text { dengan } \\
\text { benar, jika } \\
\text { salah maka } \\
\text { akan keluar } \\
\text { dialog box } \\
\text { untuk } \\
\text { diinput } \\
\text { ulang }\end{array}$ & sesuai \\
\hline 2 & $\begin{array}{l}\text { Mengklik } \\
\text { menu yang ada }\end{array}$ & $\begin{array}{l}\text { menampilkan } \\
\text { form menu } \\
\text { sesuai dengan } \\
\text { klik menu }\end{array}$ & & sesuai \\
\hline 3 & $\begin{array}{l}\text { menginput } \\
\text { master User } \\
\text { lalu di simpan }\end{array}$ & $\begin{array}{l}\text { tersimpan ke } \\
\text { dalam } \\
\text { database } \\
\text { sesuai dengan } \\
\text { hasil inputan } \\
\text { tidak ada error }\end{array}$ & & sesuai \\
\hline 4 & $\begin{array}{l}\text { menginput } \\
\text { Data Ruangan } \\
\text { dan terintegrasi } \\
\text { dengan } \\
\text { Aplicares BPJS } \\
\text { Kesehatan }\end{array}$ & $\begin{array}{l}\text { tersimpan ke } \\
\text { dalam } \\
\text { database } \\
\text { Internal RS } \\
\text { dan Aplicares } \\
\text { BPJS } \\
\text { Kesehatan } \\
\text { sesuai dengan } \\
\text { hasil inputan, } \\
\text { tidak ada error }\end{array}$ & $\begin{array}{l}\text { Nilai data } \\
\text { dashboard } \\
\text { internal RS } \\
\text { sama dengan } \\
\text { Dashboard } \\
\text { Aplicares }\end{array}$ & sesuai \\
\hline 5 & $\begin{array}{l}\text { mengubah data } \\
\text { master user }\end{array}$ & $\begin{array}{l}\text { tersimpan ke } \\
\text { dalam } \\
\text { database } \\
\text { sesuai dengan } \\
\text { ubahan dan } \\
\text { tidak ada error }\end{array}$ & & sesuai \\
\hline 6 & $\begin{array}{l}\text { mengubah data } \\
\text { Ruangan }\end{array}$ & $\begin{array}{l}\text { tersimpan ke } \\
\text { dalam } \\
\text { database } \\
\text { Internal RS } \\
\text { dan Aplicares } \\
\text { BPJS } \\
\text { Kesehatan } \\
\text { sesuai dengan } \\
\text { ubahan, tidak } \\
\text { ada error } \\
\end{array}$ & $\begin{array}{l}\text { Nilai data } \\
\text { dashboard } \\
\text { internal RS } \\
\text { sama dengan } \\
\text { Dashboard } \\
\text { Aplicares }\end{array}$ & sesuai \\
\hline 7 & $\begin{array}{l}\text { Melihat } \\
\text { laporan }\end{array}$ & $\begin{array}{l}\text { Menampilkan } \\
\text { hasil sesuai } \\
\text { dengan } \\
\text { periode } \\
\text { dipilih } \\
\end{array}$ & & sesuai \\
\hline
\end{tabular}




\subsection{Pemeliharaan}

Pemeliharaan adalah salah satu cara yang harus dilakukan dengan cara melakukan backup secara berkala dan otomatis baik dari segi hosting maupun dari segi database. Hal ini berfungsi untuk menghindari kehilangan data ketika terjadi hal-hal yang tidak diinginkan. Dalam hal ini Backup dilakukan dengan 3 aturan yaitu:

a. BackUp Harian, dilakukan setiap hari pada jam 00.30 Wib

b. Backup Mingguan, selakukan setiap hari minggu pada pukul $12.00 \mathrm{Wib}$

c. BackUp Bulanan, dilakukan setiap bulan pada pukul 16.00 Wib

\section{KESIMPULAN}

Berdasarkan dari hasil pembahasan diatas maka dapat diambil kesimpulan sebagai berikut:

a. Aplikasi Sistem Informasi Ketersediaan Rumah Sakit Terintegrasi dengan Aplicares BPJS Kesehatan yang dibuat sangat membantu rumah sakit yang tidak mempunyai tenaga ahli pemrograman. Karena aplikasi ini dapat digunakan oleh rumah sakit lain hanya dengan mengganti Cons Id dan Key ID yang diberikan IT BPJS Kesehatan

b. Metode waterfall sangat cocok digunakan dalam membangun sebuah sistem baru dengan cepat dan mudah. Metode ini sangat baik juga digunakan terutama dalam hal kelanjutan pengembangan sistem dengan dokumentasi yang lengkap.

\section{REFERENSI}

Arikunto, S. (2006). Metodologi penelitian. Yogyakarta: Bina Aksara.

BPJS. (2018a). 370 Rumah Sakit di Indonesia Sudah
Terapkan Pendaftaran Online. Retrieved from https://bpjs-

kesehatan.go.id/bpjs/index.php/post/read/2018 /715/370-Hospital-in-Indonesia-AlreadyApply-Online-Registration

BPJS. (2018b). Jaminan Kesehatan Semesta sudah di Depan Mata. Retrieved from https://bpjskesehatan.go.id/bpjs/index.php/post/read/2018 /639/Jaminan-Kesehatan-

Jogiyanto, H. M. (2005). Analisa dan Desain Sistem Informasi Pendekatan Terstruktur Teori dan Praktik Aplikasi Bisnis. Yogyakarta : Andi.

Kendall, K. E., \& Kendall, J. E. (2010). Analisis Dan Perancangan Sistem. Jakarta:Indeks.

Riyandi, A. (2018). Perancangan Aplikasi Sistem Informasi Tiket Masuk (STIK-MA) Berbasis Desktop. Seminar Nasional Rekayasa Teknologi Informasi, 01, 65-70. Retrieved from http://ejurnal.lppmunsera.org/index.php/snartisi/articl e/view/807/715

S, R. A., \& Shalahuddin, M. (2014). Rekayasa Perangkat Lunak Terstruktur dan Berorientasi Objek. Bandung: Penerbit Informatika.

Sugiono. (2010). Metode Penelitian Pendidikan Pendekatan Kuantitatif kualitatif dan $R \& D$. Bandung: Alfabeta.

Sutabri, T. (2012). Konsep Dasar Informasi. Yogyakarta : Andi.

Sutanta, E. (2011). Basis Data dalam Tinjauan Konseptual . Yogyakarta : Andi.

\section{PROFIL PENULIS}

Penulis saat ini bekerja sebagai Tim Pembangunan IT di salah satu Rumah Sakit Swasta nasional. Penulis juga aktif mengajar di Universitas Bina Sarana Informatika dan STMIK Nusa Mandiri. 